\title{
Effect of harvesting date on fruit quality of grapefruit cv. 'Red Blush' under Jordan Valley conditions
}

\author{
Jalal MUHTASEB
}

National Center for Agriculture Research and Technology Transfer (NCARTT), PO Box: 639, 19381 Baq'a, Jordan

Jalall2@hotmail.com

* Correspondence and reprints

Fruits, 2007, vol. 62, p. 107-113 (c) 2007 Cirad/EDP Sciences All rights reserved

DOI: $10.1051 /$ fruits:2007004 www.edpsciences.org/fruits

RESUMEN ESPAÑOL, p. 113

\section{Effect of harvesting date on fruit quality of grapefruit cv. 'Red Blush' under Jordan Valley conditions.}

Abstract - Introduction. The grapefruit tree has a long production period. In the Jordan Valley, harvest lasts from November to March. Many Jordanian farmers tend to harvest their fruit early to get high prices, regardless of its quality. Thus, the effect of the harvesting date on fruit quality of grapefruit cv. 'Red Blush' was evaluated under Jordan Valley conditions for two seasons, 2002 and 2003. Materials and methods. Fruit quality of uniform 25-year-old grapefruit cv. 'Red Blush' trees budded on sour orange rootstock was studied during the 2002 and 2003 seasons. Fruits were harvested from October 15 in both seasons with 15-day intervals with a total of eight harvests. The studied data were total soluble solids (TSS), titratable acidity (TA), the [TSS/ TA] ratio and juice percentage. Results and discussion. Fruit total soluble solids and fruit juice percentages were at a minimal level during early harvesting dates and increased with time, reaching the maximum level on January 1 for TSS and January 15 for fruit juice percentage in the first season and on December 15 and February 1, respectively, in the second season, after that TSS decreased. Fruit titratable acidity values were at maximal levels during early harvesting dates (October 15) and decreased with time, reaching the minimum level on February 1 in the first season and on January 15 in the second season. The [TSS/TA] ratio ranged from 5.5 to 6.0 between January 1 and February 1 in the first season, and between December 1 and January 15 in the second season. Conclusion. Our study displayed that Jordan Valley growers are harvesting their grapefruits much too early to provide acceptable eating quality fruits to local markets.

Jordan / Jordan river / Citrus paradisi / fruits / harvesting date / climate / quality

Effet de la date de récolte sur la qualité du pamplemousse 'Red Blush' dans les conditions de la vallée du Jourdan.

Résumé - Introduction. Le pamplemoussier a une longue période de production. Dans la vallée du Jourdan, la récolte dure de novembre à mars. Beaucoup de producteurs jordaniens ont tendance à récolter leur fruit en avance afin d'obtenir des prix élevés, sans prendre en compte sa qualité. Nous avons donc étudié l'effet de la date de la récolte sur la qualité du pamplemousse 'Red Blush' dans les conditions propres à cette région, pendant deux saisons, 2002 et 2003. Matériel et méthodes. La qualité du pamplemousse 'Red Blush' sur des arbres de 25 ans greffés sur oranger amère a été étudiée pendant les saisons 2002 et 2003. Des fruits ont été récoltés à partir du 15 octobre au cours des deux saisons, à raison d'une récolte tous les 15 jours et de huit dates de prélèvement. Les données étudiées ont porté sur l'extrait sec soluble (ESS), l'acidité titrable (AT), le rapport [ESS/TA] et le pourcentage de jus. Résultats et discussion. Le pourcentage de jus de fruit et le taux d'ESS ont été minimaux pendant les dates de la récolte précoces et ont augmenté au cours du temps jusqu'à un maximum au $1^{\mathrm{er}}$ janvier pour l'ESS et au 15 janvier pour le pourcentage de jus de fruit pour 2002 et au 15 décembre et $1^{\mathrm{er}}$ février, respectivement, pour 2003, ensuite les taux d'ESS ont diminué. Les valeurs d'AT du fruit ont été maximales lors des premières dates de récolte ( 15 octobre) puis elles ont diminué avec le temps, atteignant leur minimum le $1^{\text {er }}$ février en 2002 et le 15 janvier en 2003. Le rapport [TSS/TA] a varié de 5,5 à 6,0 entre le $1^{\mathrm{er}}$ janvier et le $1^{\mathrm{er}}$ février 2002 et entre le $1^{\mathrm{er}}$ décembre et le 15 janvier 2003. Conclusion. Notre étude a montré que les producteurs de la vallée du Jourdan récoltent leurs pamplemousses beaucoup trop tôt pour fournir les fruits présentant une qualité acceptable pour leur commercialisation sur les marchés locaux.

Jordanie / Jourdain / Citrus paradisi / fruits / date de récolte / climat / qualité 


\section{Introduction}

'Red Blush' grapefruit (Citrus paradisi Macf.) is one of the most popular pigmented grapefruit varieties planted mostly in the Jordan Valley; the area planted is 230 ha, producing 4000 t yearly [1]. The Jordan Valley is characterized by a dry warm subtropical climate, making grapefruit prospers, due to its high heat requirements [2]. Grapefruit has a long production period, lasting in the Jordan Valley from November to March. Therefore, in order to get high prices, many Jordanian farmers tend to harvest their fruits as early as November since no or little citrus fruit is exported. This early harvesting will cause some internal fruit quality problems, including undersized fruits and low internal quality (e.g., high acidic fruit, low total soluble solids (TSS), low juice content, etc.). Fruit marketable quality is largely determined by the stage of development of fruit at harvest. Consequently, fruit picked while immature is likely to be small, poorly colored, off-flavored and more susceptible to diseases when stored. Over-mature fruit, besides having a shorter storage life, has poor storage quality and is susceptible to granulation,

\section{Figure 1.}

Minimum and maximum temperatures registered during the 2002 and 2003 seasons and over 5 years in Wadi Al-Rayyan, Jordan Valley (Jordan). chilling injury and fruit rotting [3, 4].

Climatic conditions during maturation, particularly thermal regimes, may affect both growth and fruit ripening aspects, including the length of time from flowering to fruit

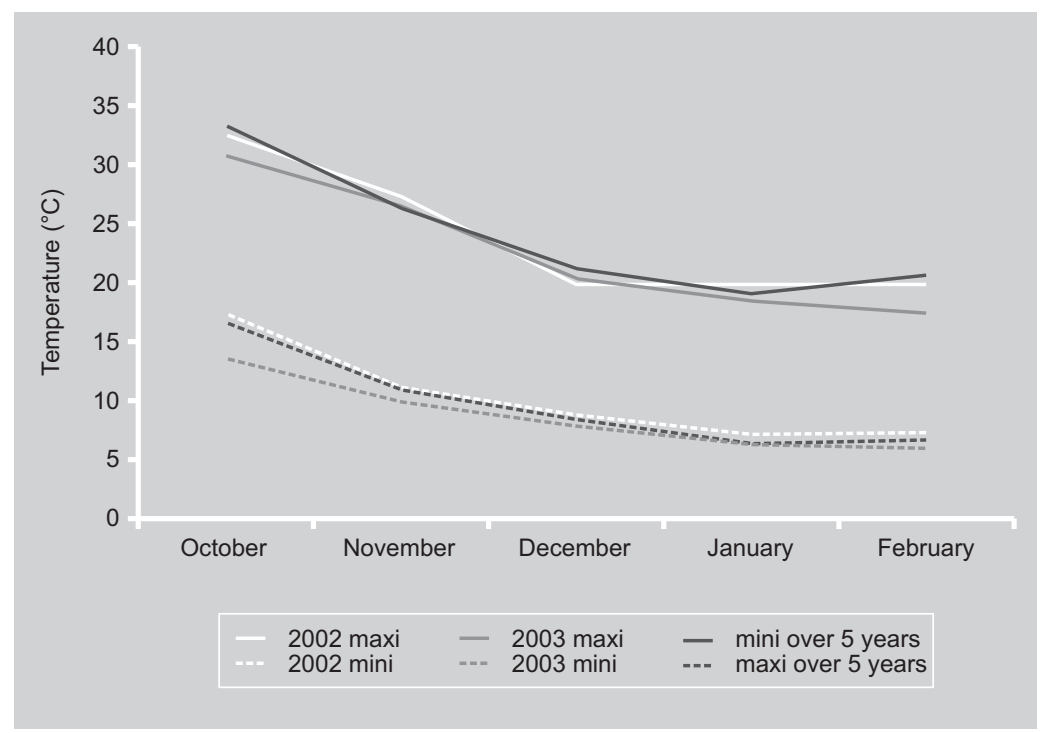

maturity $[2,5,6]$, leading to quite huge variations in fruit quality at harvest from one season to another. On the other hand, the effect of relative humidity on citrus fruit is difficult to be isolated from other environmental factors; however, a citrus tree under a high relative humidity climate tends to produce fruit with smoother and thinner skin, while in an arid climate, the peel is thicker and rougher and the juice content is lower $[2,5]$. Therefore, grapefruit achieves its best quality under conditions of hot days and warm to hot nights, which result in higher sugars and lower acids than those produced in the cooler night temperatures [5].

The effect of harvesting date on fruit quality has been reported in many studies [7-9]. Moreover, the harvesting date especially affected fruit weight, rind thickness, juice content, fruit marketability, fruit disorders, titratable acidity and soluble solids in citrus varieties [10-13]. Suitable conditions for 'Valencia' oranges were found for those fruits harvested at the beginning of April [14], which is quite a late harvest date. Ahmad et al. [15] reported changes in fruit internal quality (e.g., TSS, acidity, ascorbic acid, total, reducing and non-reducing sugars, and the sugar/acid ratio) in the fruit of three grapefruit cultivars with different harvesting dates. However, the "on-tree storage" or late harvesting of mature grapefruits and 'Valencia' fruits exerts a continuing demand for carbohydrates and water, which may reduce the following year's crop $[2,16$, 17]. Our study was carried out to evaluate the effect of harvesting date on fruit quality of grapefruit cv. 'Red Blush' grown under the Jordan Valley climatic conditions.

\section{Materials and methods}

Our experiment was conducted in Wadi AlRayyan, northern Jordan Valley, during the 2002 and 2003 seasons. Five uniform 25year-old grapefruit cv. 'Red Blush' trees grafted onto sour orange rootstock, $6 \mathrm{~m} \times$ $6 \mathrm{~m}$ spacing, were used. Each tree represented one replicate. The trees were grown using similar cultural practices of irrigation, fertilization, pest management and weeding to those of producers of the Jordan Valley. 
The orchard soil texture was clay, $\mathrm{pH}$ was 8.2, electrical conductivity (EC) was $1.0 \mathrm{dS} \cdot \mathrm{m}^{-1}$ and $\mathrm{CaCO}_{3}$ content was $35.0 \%$.

Eight 15-day-interval harvests were carried out, beginning on October 15 , in both seasons. For each date, $20 \mathrm{~kg}$ of fruit from each replicate (tree) were randomly collected at the periphery of the tree. Fruits were washed and cut into halves. Juice was extracted using a Braun ${ }^{\circledR}$ citromatic and weighed to calculate the juice percentage $(\mathrm{w} / \mathrm{w})$. The juice was filtered by Whatman ${ }^{\circledR}$ filter paper No. 1 to exclude juice sacs and other precipitates. Total soluble solids (TSS) percentage was measured using a Fisher ${ }^{\circledR}$ refractometer, and juice $\mathrm{pH}$ using a $\mathrm{pH}$ meter (Hanna ${ }^{\circledR}$ Instruments). Finally, juice titratable acidity (TA), expressed as citric acid percentage, was determined by titration with $0.1 \mathrm{~N} \mathrm{NaOH}$ [18]. The [TSS / TA] ratio was also calculated as a maturity parameter [19]. Climatic data of air temperatures and relative humidity were recorded using a fully computerized meteorological station at the site of the study, and the average per month was calculated.

The collected data were statistically analyzed by ANOVA according to a randomized complete block design with five replicates, and mean separation was calculated according to the Least Significant Differences (LSD) method at the 5\% level using MSTAT software.

\section{Results and discussion}

\subsection{Climatic data}

Maximum and minimum temperatures during both seasons and during the 5-year record were high in October and decreased until February. Maximum temperatures ranged from $32.6{ }^{\circ} \mathrm{C}$ to $19.9^{\circ} \mathrm{C}$ during the 2002 season and from $30.7^{\circ} \mathrm{C}$ to $17.5^{\circ} \mathrm{C}$ during the 2003 season; minimum temperatures ranged from $17.3^{\circ} \mathrm{C}$ to $7.4^{\circ} \mathrm{C}$ during the 2002 season and from $13.7^{\circ} \mathrm{C}$ to $6.2^{\circ} \mathrm{C}$ during the 2003 season (figure 1). The opposite occurred for relative humidity (RH): RH values were low in October and increased until February. Maximum RH ranged from (86.6

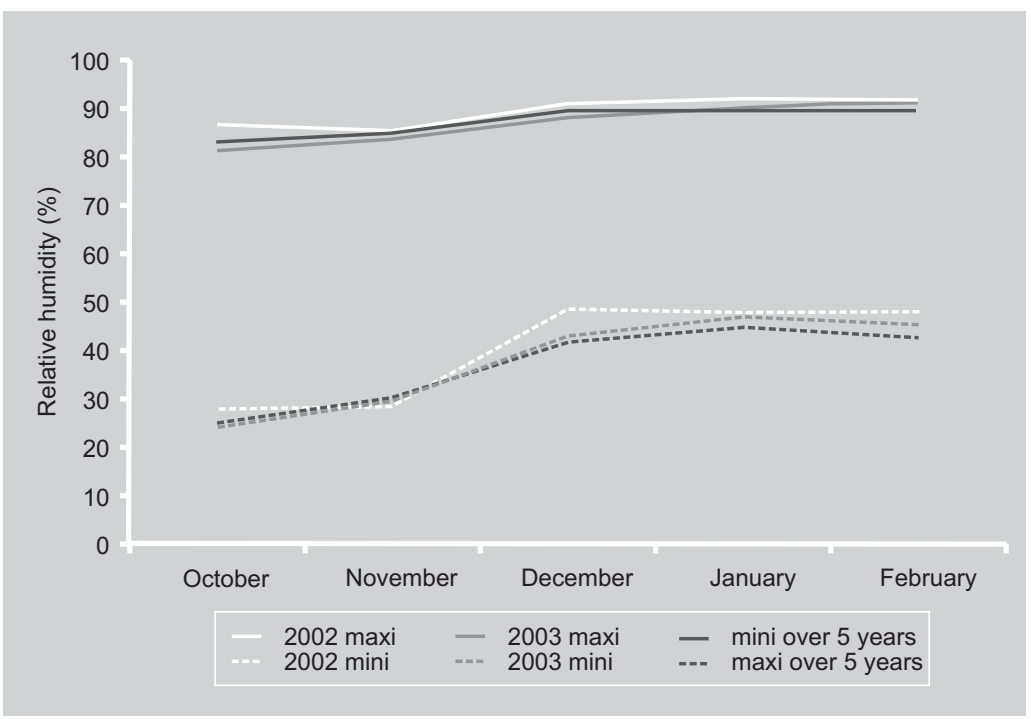

to 91.0$) \%$ during the 2002 season and from (81.2 to 90.8$) \%$ during the 2003 season; minimum $\mathrm{RH}$ ranged from (27.7 to 48.0)\% during the 2002 season and from (24.4 to 45.3$) \%$ during the 2003 season (figure 2).

When comparing the climatic conditions for the two growing seasons with the 5-year average, both the minimum and maximum temperatures of the 5-year record were slightly higher than those of the 2003 season, and the minimum relative humidity of the 5-year average was slightly lower than that of both seasons. In addition, when comparing the climatic conditions for the two growing seasons, both temperature and

Figure 2.

Minimum and maximum relative humidity registered during the 2002 and 2003 seasons and over 5 years in Wadi Al-Rayyan, Jordan Valley (Jordan).

\section{Figure 3.}

Effect of harvesting date on fruit total soluble solids of grapefruit cv. 'Red Blush' during the 2002 and 2003 seasons in Wadi AlRayyan, Jordan Valley (Jordan). Means with the same letter, for the same year, are not significantly different at $P<5 \%$.

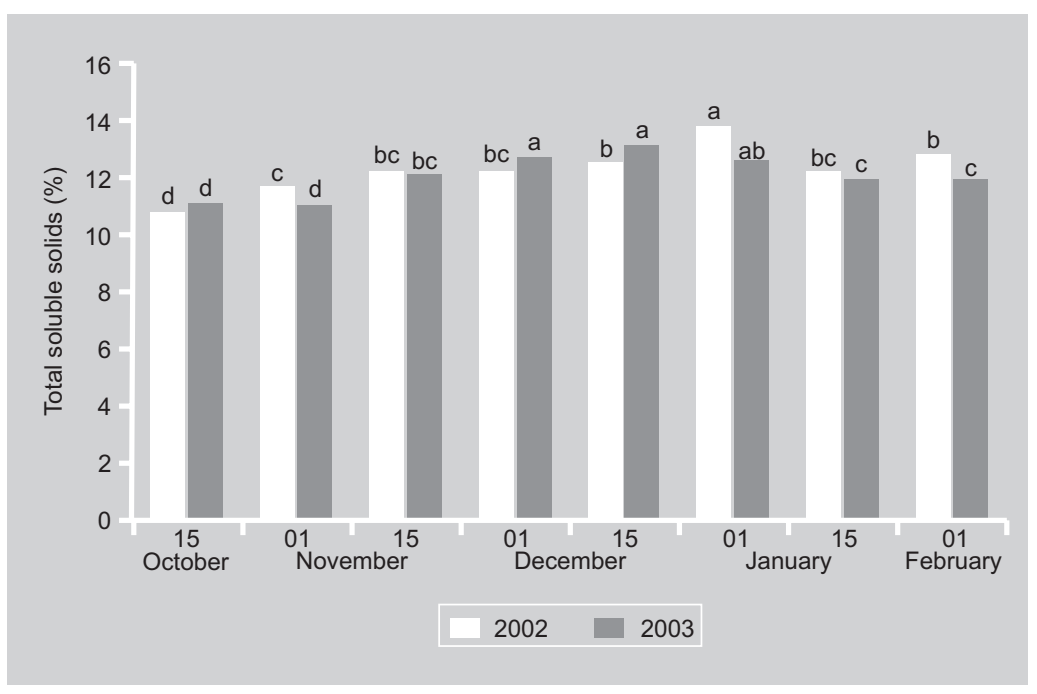




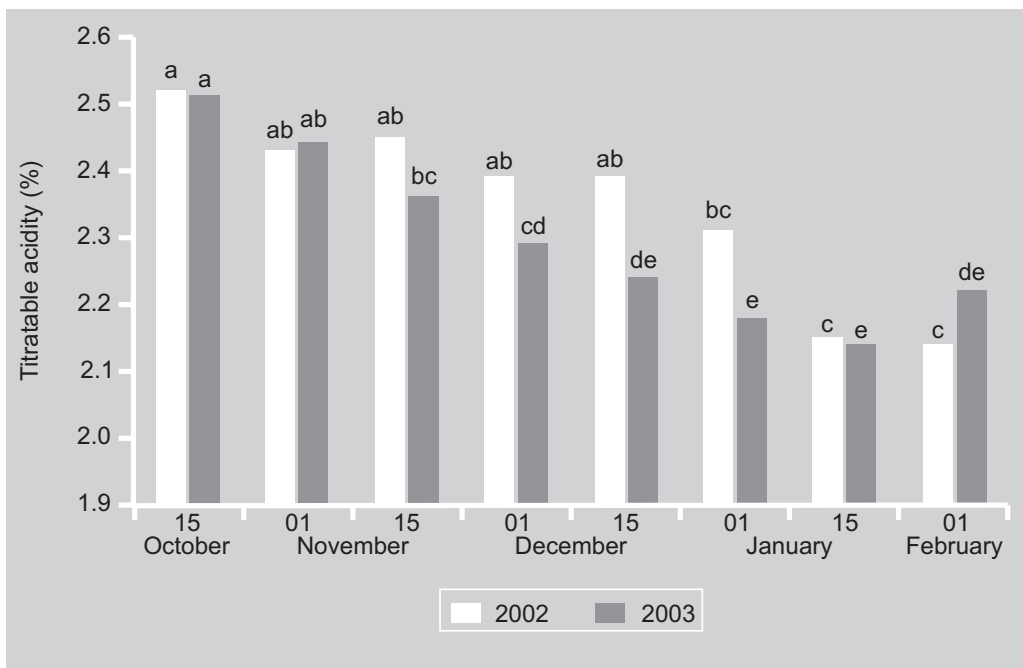

Figure 4.

Effect of harvesting date on fruit RH were slightly higher during the 2002 titratable acidity of grapefruit cv. season than during the 2003 season 'Red Blush' during the 2002 and (figures 1, 2). 2003 seasons in Wadi

Al-Rayyan, Jordan Valley (Jordan).Means with the same letter, for the same year, are not significantly different at $P<5 \%$.

Figure 5.

Effect of harvesting date on the [TSS / TA] ratio of grapefruit cv. 'Red Blush' during the 2002 and 2003 seasons in Wadi Al-Rayyan, Jordan Valley (Jordan). Means with the same letter, for the same year, are not significantly different at $P<5 \%$.

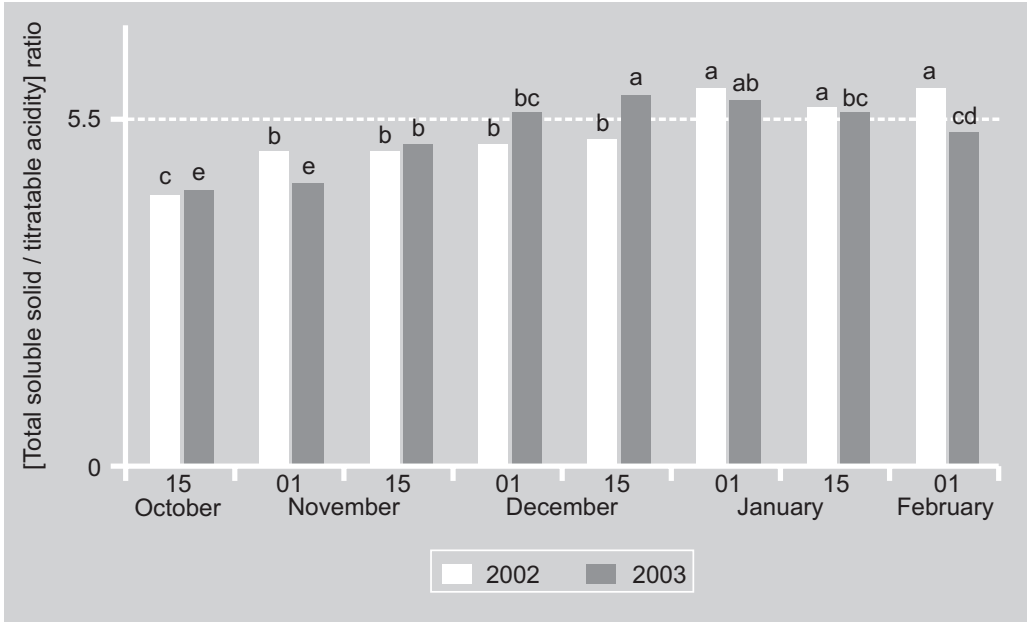

Ahmad et al. [15], who noticed a progressive increase in total soluble solids of citrus juice as harvesting advanced. Jungsakulrujirek and Noomhorm [12] noticed an increase in tangerine TSS (14.0\%) with a later than with a normal harvesting date (11.0\%). In addition, Cooper et al. [20] found a progressive increase in TSS concentration of 'Valencia' juice from early November through February and it ranged from (7.8 to 12.1)\%, respectively. The author related this early high TSS to warm nights during the fall.

On the contrary, fruit titratable acidity values (TA\%) were at the maximal levels for the first harvest date $(2.52 \%$ for the 2002 season, and $2.51 \%$ for the 2003 season) and decreased with time, reaching the minimum level on February 1 in the first season, and on January 5 in the second season $(2.14 \%$ for both seasons) (figure 4). Our results were in agreement with those of Reuther [5], Reuther et al. [6], and Jungsakulrujirek and Noomhorm [12], who noticed a distinct declining trend in titratable acidity as maturation progressed and, in the same manner, in Ahmad et al.'s study [15], maximum acidity was noted in three grapefruit cultivars when fruits were harvested early. Cooper et al. [20] noticed a decrease in acid concentration of 'Valencia' orange juice from 2.86\% in November to $1.01 \%$ in March. The slow decrease in juice acid concentration during October to December might be due to the cool temperatures prevailing during that period, since there is an inverse relationship between the prevailing temperature and the rate of acid decrease, especially during the latter half of fruit growth and maturation $[5,20]$.

The [TSS/TA] ratio of 'Red Blush' grapefruit juice increased with time, from 4.3 to 6.0 for the 2002 season, and 4.4 to 5.9 for the 2003 season. According to Arpaia and Kader [21], the minimum ratio of the grapefruit maturity standards would be between 5.5 and 6.0, which occurred in this study from January 1 to February 1 in the first season, and from December 1 to January 15 in the second season (figure 5). Thus, according to this standard, all former harvests in both seasons were run too early. However, under different conditions, Ahmad et al. [15] found that fruits of three grapefruit cultivars 
obtained a maximum [sugar / acid] ratio during November and December. Reuther [5] and Reuther et al. [6] reported that the concentration of total acids is the most sensitive and consistent juice component in response to climatic differences. Cooper et al. [20] noticed an increase in the [sugar / acid] ratio of 'Valencia' orange juice from 2.8 in November to 10.0 in February. Jungsakulrujirek and Noomhorm [12] noticed an increase in the [TSS / TA] ratio of tangerine fruits at later stages of maturity, indicating better flavor. The relatively cool temperature from December to January (figure 1) was responsible for the slow decrease in acidity that we measured in our study: also, the cool nights in October and November were not beneficial for significantly affecting the [TSS / TA] ratio. Such prevailing thermal regimes did not favor early grapefruit maturity in spite of the TSS being high, because the TA content had not decreased sufficiently to meet the minimum acceptable [TSS / TA] ratio values of the grapefruit maturity standards [5]. Therefore, under such prevailing climatic conditions in the Jordan Valley, early grapefruit harvesting should be avoided.

Finally, fruit juice percentages were at minimal levels at the first harvest (43.1\% for the 2002 and $35.7 \%$ for the 2003 seasons), and increased with time, reaching the maximum levels on the latest harvesting dates for both seasons (49.6\% for 2002 and $48.0 \%$ for 2003) (figure 6 ). These results were consistent with those of Reuther et al. [6] and Jungsakulrujirek and Noomhorm [12], who noticed a trend of increasing juice content up to a point, after which it declined later in the season. Cooper et al. [20] reported an increase in 'Valencia' orange juice content from (31 to 58)\% during November through February. In several studies regarding the effect of harvesting date in relation to climatic conditions, juice content of citrus fruit was mainly related to the amount of moisture in the climate; juice content was higher in moist climates rather than in drier locations [5, 6, 20]. However, fruit juice percentages throughout the 2002 season were higher in comparison with the 2003 season (figure 6).

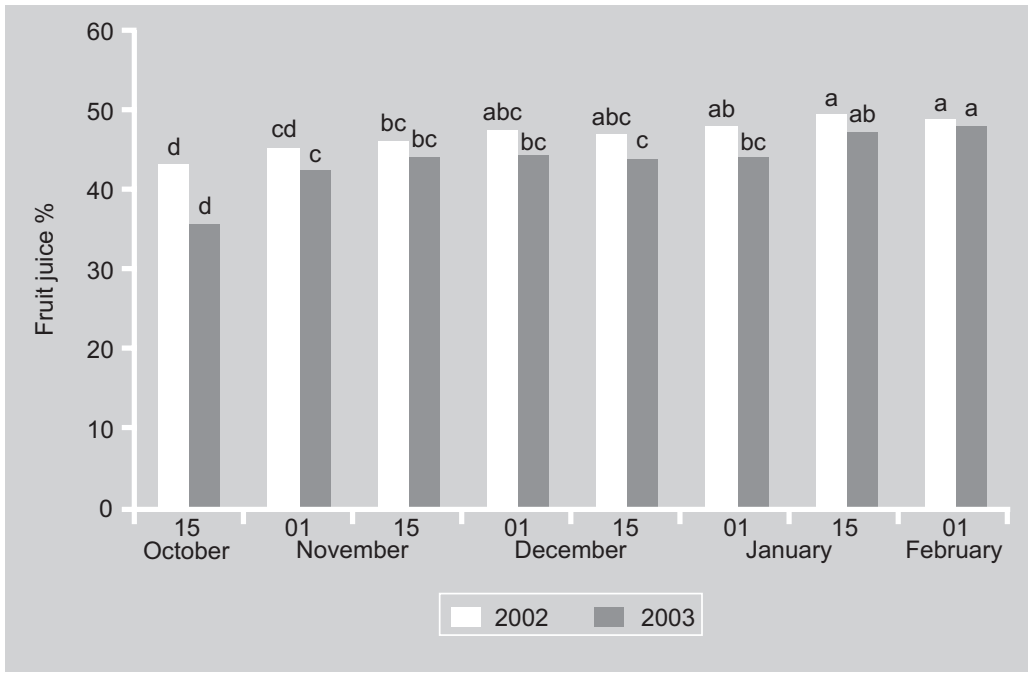

\section{Conclusion}

Grapefruit growers in the northern Jordan Valley tend to harvest their crop as early as November to get high prices, regardless of its internal fruit quality. This common practice in the Jordan Valley does not provide fruit with acceptable eating quality to local markets, since it has low total soluble solids (TSS), high acidic fruits, low juice content and a low [TSS / TA] ratio. In addition to that, the prevailing climatic conditions at the place of the study do not encourage this early grapefruit harvesting.

Our study showed that, in order to harvest grapefruit cv. 'Red Blush' with high and acceptable internal fruit quality, citrus growers of the northern Jordan Valley should not harvest their grapefruits before January.

\section{References}

[1] Anon., Crop statistics report, Hashemite Kingd. Jordan, Dep. Stat. (DOS), Amman, Jordan, 2005.

[2] Morton J., Grapefruit, in: Fruits of warm climates, Creat. Res. Syst., inc., Miami, FL, USA, 1987.

[3] Burns J.K., Albrigo L.G., Time of harvest and method of storage affect granulation in grapefruit, HortScience 33 (1998) 728-730.

\section{Figure 6.} Effect of harvesting date on fruit juice percentage ( $w / w)$ of grapefruit cv. 'Red Blush' during the 2002 and 2003 seasons in Wadi Al-Rayyan, Jordan Valley (Jordan). Means with the same letter, for the same year, are not significantly different at $P<5 \%$. 
[4] Schirra M., Agabbio M., D'hallewin G., Pala M., Ruggiu R., Response of tarocco oranges to picking date, postharvest hot water dips, and chilling storage temperature, J. Agric. Food Chem. 45 (1997) 3216 -3220, 1997.

[5] Reuther W., Climate and citrus behavior, in: Reuther W., Batchelor L.D., Webber H.J. (Eds.), The citrus industry, Div. Agric. Sci., Univ. Calif., Berkeley, CA, USA, 1973.

[6] Reuther W., Rasmussen G.K., Hilgeman R.H., Caboon G.A., Cooper W.C., A comparison of maturation and composition of 'Valencia' oranges in some subtropical zones of the United States, J. Am. Soc. Hortic. Sci. 94 (1969) 144-157.

[7] Costa G., Quadretti R., Succi A., Morigi M., Influence of harvest time and temperature on fruit quality and storage of kiwifruit (cv. Hayward), Acta Hortic. 444 (1997) 517-522.

[8] Lechaudel M., Joas J., Quality and maturation of mango fruits $\mathrm{cv}$. Cogshall in relation to harvest date and carbon supply, Aust. J. Agric. Res. 57 (4) (2006) 419-426.

[9] Rizzolo A., Grassi M., Eccher Zerbini P., Influence of harvest date on ripening and volatile compounds in the scab-resistant apple cultivar 'Golden Orange', J. Hortic. Sci. Biotechnol. 81 (4) (2006): 681-691.

[10] Ahmad M.J., Malik M.N., Maqbool M., Jaffar M., Effect of various harvesting times and different wrapping materials [butter paper, newspaper and polyethylene] on physical characteristics and storage behavior of feutrell's early mandarin (Citrus reticulata Blanco), J. Agric. Res. 28 (1990) 453-461.

[11] Chavez Sierra C.B., Bosquez Molina E., Pelayo Zaldivar C., Perez Flores L., Ponco de Leon Garcia L., Effect of harvesting season and post harvest treatments on storage life of Mexican limes (Citrus aurantifolia Swingle), J. Food Qual. 16 (5) (1993) 339-354.

[12] Jungsakulrujirek S., Noomhorm A., Effect of harvesting time and fruit size on titratable acidity, soluble solids and distribution of limonin in Thi tangerine juice, Int. J. Food Sci. Technol. 33 (4) (1998) 367-374.

[13] Dou H., The influence of harvesting time and geographical location susceptibility to physiological peel disorders associated with four Florida grapefruit cultivars, J. Hortic. Sci. Biotechnol. 80 (4) (2005) 466-470.

[14] Pekmezci M., Erkan M., Demirkol A., The effects of harvest time and different postharvest applications on the storage of 'Valencia' oranges, Acta Hortic. 398 (1995) 277-284.

[15] Ahmad M.J., Maqbool M., ljaz M., Kayani M.Z., Chemical changes in grape fruit (Citrus paradisi Macf.) during maturation and storage, J. Agric. Res. 30 (1992) 489-494.

[16] Jones W.W., Embleton T.W., Steinacker M.L. Cree C.B., The effect of time of fruit harvest on fruiting and carbohydrate supply in the 'Valencia' orange, J. Am. Soc. Hortic. Sci. 84 (1964) 152-157.

[17] Hilgeman R.H., Dunlap J.A. Sharples G.C., Effect of time of harvest of 'Valencia' oranges on leaf carbohydrate content and subsequent set of fruit, J. Am. Soc. Hortic. Sci. 90 (1967)110-116.

[18] Anon., Official methods of analysis, Assoc. Off. Anal. Chem. (AOAC), 11th ed., Washington, D.C., USA, 1970.

[19] Russo G., Comparative studies of two orange cultivars 'Navelate' and 'Valencia Late', Proc. Int. Soc. Citric. 1 (1984) 77-81.

[20] Cooper W.C., Paynado A., Furr J.R., Hilgeman R.H., Cahoon G.A., Boswell S.B., Tree growth and fruit maturity of Valencia oranges in relation to climate, Proc. Am. Soc. Hortic. Sci. 82 (1963) 180-192.

[21] Arpaia M., Kader A., Grapefruit, recommendations for maintaining postharvest quality, Postharvest Technol. Res. Inf. Cent., Dep. Pomol., Univ. Calif., USA, 2000. 


\section{Efecto de la fecha de cosecha en la calidad del pomelo 'Red Blush' en las condiciones del valle de Jordán.}

Resumen - Introducción. El pomelo posee un largo periodo de producción. En el valle de Jordán la cosecha dura desde noviembre hasta marzo. Sendos productores jordanos tienden a cosechar sus frutos con antelación con el fin de obtener los precios elevados, sin tener en cuenta su calidad. Por ello estudiamos el efecto de la fecha de cosecha sobre la calidad del pomelo 'Red Blush' en las condiciones propias de esta región, durante dos temporadas, 2002 y 2003. Material y métodos. Se estudió la calidad del pomelo 'Red Blush' en los árboles de 25 años injertados en naranjo amargo durante las temporadas de 2002 y de 2003 . Se cosecharon frutos a partir del 15 de octubre a lo largo de dos temporadas, a razón de una cosecha cada 15 días y de ocho fechas de muestreo. Los datos estudiados se refirieron al extracto seco soluble (ESS), a la acidez titrable (AT), a la relación [ ESS/TA], así como al porcentaje de jugo. Resultados y discusión. El porcentaje de jugo de fruto y el porcentaje de ESS fueron mínimos durante las fechas de cosecha precoces y aumentaron a lo largo del tiempo hasta alcanzar un máximo el $1^{\circ}$ de enero en cuanto al ESS y el $15^{\circ}$ de enero para el porcentaje de jugo de fruta para el 2002; y, el 15 de diciembre y el 1 de febrero, respectivamente, para el 2003; después disminuyeron los porcentajes de ESS. Los valores de AT del fruto fueron máximos durante las primeras fechas de cosecha (15 de octubre); y, disminuyeron con el tiempo, alcanzando su punto mínimo el $1^{\circ}$ de febrero en el 2002 y el 15 de enero en el 2003. La relación [ TSS/TA ] varió de 5.5 a 6.0 entre el 1 de enero y el 1 de febrero de 2002, así como entre el 1 de diciembre y el 15 de enero de 2003. Conclusión. Nuestro estudio mostró que los productores del valle de Jordán cosechan sus pomelos demasiado pronto como para suministrar los frutos que presenten una calidad aceptable para su comercialización en los mercados locales.

Jordania / Río Jordán / Citrus paradisi / frutas / fecha de recolección / clima / calidad 